\title{
Inhalt / Table of Contents
}

\author{
Enzo De Pellegrin, Vienna
}

The Brown Book of Alice Ambrose

Remarks on Ludwig Wittgenstein's dictated notes of $1934-35-1$

Werner Stegmaier, Greifswald

Die Gewissheit der Orientierung

Zu Wittgensteins letzten Notaten. Ein Versuch — 37

Francis Y. Lin, Beijing

Wittgenstein on Thinking as a Process or an Activity -73

Melanie Uth, Köln

Möchte Chomsky erklären, was Wittgenstein beschreibt?

Das Verhältnis der sprachphilosophischen Aussagen von Noam Chomsky und Ludwig Wittgenstein 105

Timo-Peter Ertz, Giessen

Farbe und Raum

Wittgenstein über weiß und trübe -125

Alois Pichler, Bergen

A Brief Update on Editions Offered by the Wittgenstein Archives at the University of Bergen and Licences for their Use (as of June 2018) — 139

Special Section: Wittgenstein and Applied Epistemology - 147

Edited by Nuno Venturinha, Lisbon

Natalie Alana Ashton, Vienna

The Case for a Feminist Hinge Epistemology — 153

Anna Boncompagni, Irvine

Hinges, Prejudices, and Radical Doubters — 165

Marco Brusotti, Berlin / Lecce

Knowing our own Body?

Wittgenstein and the Epistemology of Bodily Self-experience — 183 
Michel Le Du, Aix-Marseille

The Myth of the Thinking Brain 201

Andrew Lugg, Montreal

Wittgenstein and Scientific Representation — 211

Sofia Miguens, Porto

Temptation and Therapy

Wittgensteinian Responses to Other Minds Skepticism — 227

Constantine Sandis, Hertfordshire

Making Ourselves Understood

Wittgenstein and Moral Epistemology — 241

Genia Schönbaumsfeld, Southampton

How Threatening are Local Sceptical Scenarios? — 261

Vicente Sanfélix Vidarte and Chon Tejedor, Valencia

Experience and Religious Belief

Wittgenstein's Epistemology of Religion — 279

„Das Buch ist voller Leben ...“

Neuere Wittgenstein-Literatur $\longrightarrow 295$

Die Autorinnen und Autoren des Bandes / Authors of this Volume -321 